\title{
Alternative Weed Control Methods against Vegetation around Electrical Sites
}

\author{
MA Haidar* \\ Department of Agriculture, American University of Beirut, Lebanon
}

Submission: January 13, 2018; Published: February 05, 2018

"Corresponding author: MA Haidar, Department of Agriculture, Faculty of Agricultural and Food Sciences, American University of Beirut, Beirut 1107 2020, Lebanon,Email: mhaidar@aub.edu.lb

\section{Opinion}

There are many alternative methods available against weeds around electrical sites. Usually a single method will not be sufficient to control noxious weeds. Thus, integrating various methods is more successful and sustainable against weeds. The first defensive line is to prevent weeds from invading the site. This is almost impossible, as many weeds have morphological and physical characteristics that enable their seeds and other vegetative organs to be easily transported over long distances. But there are various ways that you can manage weeds from establishing around electrical sites. Traditionally, in such places, weeds are managed primarily through repetitive use of certain herbicides such as glyphosate, 2,4-D and others. However, such herbicides have a strong negative impact on our ecosystem and on human health. Consequently, there has been an increased interest in alternatives to traditional chemical products which can be considered as both environmentally friendly and safe for humans. Below are a few ideas that do not pose any environmental risk.

\section{Prevention}

It is very important to identify weeds as early as possible to help stop their spreading. You may be able to identify your weed by visiting various weed identification web sites, such as http://www.iwsc.org., http://www.wssa.net, etc. One of the most effective ways against weed growth is to prevent weeds from spreading, eradicating new infestations and killing the weeds and their root systems to inhibit future growth. The use of clean equipment, vehicles and machinery is an essential step to prevent weeds from invading new sites.

\section{Alternative methods to manage weed}

a. Flaming/fire. Flaming is a very popular method against weeds. It works best against annual small weeds.

b. Cutting. Use weed eaters/mowers/slashers to prevent annual weeds from setting flowers/seeds. For shrubs or trees, the stems are cut through completely, close to the ground. Glyphosate is then applied immediately to the cut surface. In case herbicides are unwanted, then you may scrape the stems. A sharp knife is used to scrape a very thin layer of bark. Some woody weeds can have their bark surface peeled away in a ring.

c. Steaming, to kill weeds. This is usually applied after cutting the weeds.

d. Scalping the top layer of soil is an effective method against weed seed banks in the soil.

e. Hand pulling or hoeing are very effective ways against annual weeds.

f. Grazing. Animal grazing is also a popular method against annual weeds, used in parallel with other methods in weed management. Cattle, goats, sheep and even horses can be used for weed management.

g. Mulching (straw, wood chips, gravel, plastic, etc.) to block light and impede weed growth around the electrical site is one of the most popular management practices which reduces weed problems. Be careful to buy weed-free organic mulches, as weed seeds can survive the mulching process.

h. Natural herbicides. There are various natural herbicides against weeds. Spraying vinegar (1/2 cup vinegar with $1 / 2$ cup of salt and 2 teaspoons of soap) on the existing weeds is one of the cheapest ways against weeds. The combination of acetic acid, salt, and soap is very effective against small annual weeds. This is a contact type herbicide. Thus, it burns plant foliage that is contacted by the product.

i. Salt. Salt is very effective against small annual weeds around electrical sites. It prevents weed growth and sprouting. Applying salt to the soil will prevent weed sprouting for some time. 
This work is licensed under Creative Commons Attribution 4.0 License

DOI:10.19080/ARTOAJ.2018.13.555900
Your next submission with Juniper Publishers will reach you the below assets

- Quality Editorial service

- Swift Peer Review

- Reprints availability

- E-prints Service

- Manuscript Podcast for convenient understanding

- Global attainment for your research

- Manuscript accessibility in different formats

( Pdf, E-pub, Full Text, Audio)

- Unceasing customer service

Track the below URL for one-step submission https://juniperpublishers.com/online-submission.php 